\title{
Bacterial and viral coinfection in idiopathic pulmonary fibrosis patients: the prevalence and possible role in disease progression
}

\author{
Mohsen Moghoofei ${ }^{1,2}$, Shayan Mostafaei ${ }^{3}$, Nasim Kondori ${ }^{4}$, Michelle E. Armstrong ${ }^{5}$ and Farhad Babae ${ }^{2^{*}}$
}

\begin{abstract}
Background: Idiopathic pulmonary fibrosis (IPF) is a progressive interstitial pneumonia of unknown aetiology with a mean survival rate of less than 3 years. No previous studies have been performed on the role of co-infection (viral and bacterial infection) in the pathogenesis and progression of IPF. In this study, we investigated the role of viral/bacterial infection and coinfection and their possible association with pathogenesis and progression of IPF.

Methods: We investigated the prevalence and impact of bacterial and viral coinfection in IPF patients $(n=67)$ in the context of pulmonary function ( $F V C, F E V_{1}$ and $\mathrm{DL}_{\mathrm{CO}}$ ), disease status and mortality risk. Using principal component analysis (PCA), we also investigated the relationship between distribution of bacterial and viral co-infection in the IPF cohort.

Results: Of the 67 samples, $17.9 \%$ samples were positive for viral infection, 10.4\% samples were positive for bacterial infection and $59.7 \%$ samples were positive coinfection. We demonstrated that IPF patients who were co-infected had a significantly increased risk of mortality compared $(p=0.031)$ with IPF patients who were non-infected [Hazard ratio: 8.12; $95 \% \mathrm{Cl} 1.3-26.9]$.

Conclusion: In this study, we report for the first time that IPF patients who were coinfected with bacterial and viral infection have significantly decreased $F V C$ and $\mathrm{DL}_{\mathrm{CO}}$ (\% predicted). Besides, the results demonstrated the increased AE-IPF, increased incidence of death and risk of mortality in infected/coinfected patients compared to non-infected IPF patients.
\end{abstract}

Keywords: Idiopathic pulmonary fibrosis, Bacterial infection, Viral infection, Coinfection

\section{Background}

Idiopathic pulmonary fibrosis (IPF) is a fatal interstitial lung disease with a mean survival rate of less than 3 years. The prevalence of IPF is estimated at up to 29 cases per 100,000 , with the incidence and associated mortality currently increasing $[1,2]$. Many risk factors have been implicated in the etiology of IPF including inhaled toxins, smoking and infectious disease $[3,4]$. However, the

\footnotetext{
*Correspondence: farhadbabaii@gmail.com

2 Department of Microbiology, Faculty of Medicine, Kermanshah

University of Medical Sciences, Kermanshah, Iran

Full list of author information is available at the end of the article
}

specific mechanisms underlying IPF pathogenesis or disease progression are unknown.

Extensive research has demonstrated a role for a number of viruses in initiation and progression of clinical disease in IPF. Previous research has demonstrated a role of viruses in initiation and progression of clinical disease in IPF [5-9]. Previously, we demonstrated the presence of parainfluenza, RSV, rhinovirus and coronavirus in nasopharyngeal (NPL) and bronchoalveolar lavage (BAL) fluid from IPF patients [4]. However, we did not investigate the impact of these viruses on pulmonary function in IPF patients. The similarities in

(c) The Author(s) 2022. Open Access This article is licensed under a Creative Commons Attribution 4.0 International License, which permits use, sharing, adaptation, distribution and reproduction in any medium or format, as long as you give appropriate credit to the original author(s) and the source, provide a link to the Creative Commons licence, and indicate if changes were made. The images or other third party material in this article are included in the article's Creative Commons licence unless indicated otherwise in a credit line to the material. If material is not included in the article's Creative Commons licence and your intended use is not permitted by statutory regulation or exceeds the permitted use, you will need to obtain permission directly from the copyright holder. To view a copy of this licence, visit http://creativecommons.org/licenses/by/4.0/. The Creative Commons Public Domain Dedication waiver (http://creativeco mmons.org/publicdomain/zero/1.0/) applies to the data made available in this article, unless otherwise stated in a credit line to the data. 
clinical and radiologic presentation between pneumonitis related to viral infection and acute exacerbation of IPF (AE-IPF) in patients illustrates the key role of viruses in the pathogenesis of IPF [10].

More recently, a role for bacterial infection has been described in the pathogenesis of IPF. Studies have demonstrated that IPF patients have an increased bacterial load in BAL fluid compared with healthy individuals or COPD patients $[11,12]$. Furthermore, it has been shown that IPF patients with an increased bacterial load in their BAL fluid at diagnosis have a significantly increased mortality risk [11]. Bacterial species such as Strepococcus, Veillonella, Haemophillus and Neisseria have been found at increased frequencies the the BAL fluid of IPF patients [11]. Recently, bacterial infection has also been implicated in disease progression during acute exacerbations in IPF (AE-IPF)[13].

In this study, we investigated the prevalence and impact of bacterial and viral co-infection in a cohort of IPF patients $(n=67)$ in the context of pulmonary function [forced vital capacity (FVC), forced expiratory volume $1\left(\mathrm{FEV}_{1}\right)$ and diffusion lung capacity for carbon monoxide $\left(\mathrm{DL}_{\mathrm{CO}}\right)$ ], disease status and mortality risk. Specifically, we determined the prevalence of: (1) six significant respiratory viral infections in IPF including influenza, parainfluenza, adenovirus, rhinovirus, coronavirus and respiratory syncytial virus (RSV); (2) the prevalence of five respiratory bacterial infections including Pseudomonas aeruginosa (P. aeruginosa), Streptococcus pneumoniae (S. pneumoniae), Staphlococcus aureus (S. aureus), Klebseilla pneumoniae (K. pneumoniae) and Haemophilus influenza (H. influenza) and (3) we also investigated the incidence of co-infection with bacteria and viruses. Using principal component analysis (PCA), we investigated the relationship between and distribution of bacterial and viral co-infection in the IPF cohort.

\section{Methods}

\section{Study population}

In this retrospective cohort study, 67 nasopharyngeal lavage (NPL) and bronchoalveolar lavage (BAL) samples were collected from IPF patients referred to hospitals of the Kermanshah University of Medical Sciences (KUMS) between June 2017 and September 2018. All acute exacerbated patients were hospitalized. Inclusion criteria were: radiological, spirometry, therapeutic, and biological data, which are considered for IPF patients by the clinical team of KUMS hospitals [2]. Exclusion criteria were: Patients with chronic hypersensitivity pneumonitis, connective tissue disease or asbestosis. The Ethical Committee of KUMS approved this study.

\section{Nucleic acid extraction}

DNA and RNA extraction were performed using $200 \mathrm{ml}$ of NPL and/or BAL specimens by QIAamp MinElute Virus Spin Kit (Qiagen, Hilden, Germany), according to the manufacturer's instructions. Extracted genomic DNA/RNA was stored at $-80{ }^{\circ} \mathrm{C}$ before use.

\section{DNA array assay for detection of viruses and bacteria}

The CLART ${ }^{\circledR}$ Pneumovir DNA array assay (Genomica, Coslada, Madrid, Spain) was used to detect a number of viruses in this study (RSV, influenza viruses, HPIV, rhinovirus, adenovirus and coronavirus) according to manufacturer's instructions and as described by us previously [4]. Detection of S. pneumonia, S. aureus and $H$. influenza was also carried out using this method.

\section{Polymerase chain reaction (PCR) for detection of bacteria}

Detection of $P$. aeruginosa was carried out by PCR analysis as described by Tyler et al. previously [14]. Detection of K. pneumoniae was confirmed by PCR based on a study by Turton et al. [15].

\section{Statistical analysis}

In this study, all data was presented as the mean \pm standard deviation for continuous variables. Categorical variables are presented as N (\%). A normality test performed for the continuous variables using Kolmogorov-Smirnov test. A Student's t-test (parametric) or the Mann Whitney test (non-parametric) was used to test for statistical significance (twotailed) between two experimental groups. Two-sided Chi square/Fisher's exact tests were used to assess the associations between IPF and the categorical variables. Principal component analysis was used in order to investigate the pattern of bacterial and virus infections, and coinfection in the patients. Kaplan-Meier survival curve analysis and log rank test were used to test timeto-death between non-infected, and bacterial-, viraland co-infection groups of IPF patients. False discovery rate (FDR) was corrected using the Benjamini-Hochberg correction method for multiple comparisons. All statistical analysis were analyzed using $\mathrm{R}$ software version 3.5.1 and STATA software versions 11.2. Statistical significance was recorded at $p<0.05$.

\section{Results}

Study subjects

A final diagnosis of IPF was made after multidisciplinary team discussion; 12 of the 79 recruited patients did not fulfill the American Thoracic Society (ATS) diagnostic criteria for IPF and were subsequently excluded from the study [2]. The remaining 67 subjects 
with IPF were predominantly men 38 (56.7\%) with the mean age $62.8(\mathrm{SD}=12.44)$ years. Twelve $(17.9 \%)$ and $55(82.1 \%)$ of patients were stable and acute exacerbation (AE-IPF). The median time from diagnosis to an acute disease status (AE-IPF) was 90 days. All IPF patients suffered chronic pneumonia, as diagnosed by CT scan in recent years. Nine of 55 (16.3\%) of the AEIPF patients had both fever and myalgia, which was suggested viral-like illness. All patients had moderately severe disease at enrollment as characterized by carbon monoxide diffusing capacity $\left(\mathrm{DL}_{\mathrm{CO}}\right)(70.5 \%$ predicted \pm 3.96$)$, Forced Expiratory Volume in $1 \mathrm{~s}\left(\mathrm{FEV}_{1}\right)$ $(70.9 \%$ predicted \pm 4.30$)$ and Forced Vital Capacity (FVC) $(75.3 \%$ predicted \pm 4.37$)$. Additional details are included in Table 1.

\section{Prevalence of bacterial-, viral- and co-infection rates in IPF patients}

Of the 67 samples collected, 12 (17.9\%) samples were positive for viral infection, 7 (10.4\%) samples were positive for bacterial infection and 40 (59.7\%) samples were positive both viral and bacterial infection (coinfection). Among the mono infections, rhinovirus (39.7\%) and $\mathrm{H}$. influenza (46\%) were detected at the highest rate in IPF patient samples. In contrast, coronavirus (14.3\%), S. aureus (25.4\%) and $K$. pneumoniae (25.4\%) were detected at the lowest rate in IPF patient samples. Additional details are included in Table 1.

\section{Effect of bacterial-, viral- and co-infection on pulmonary function in IPF patients}

Here, we carried out an analysis of the effect of viral-, bacterial- and co-infection on pulmonary function in IPF patients. In Table 2, we examined FVC, FEV1 and DLCO indices in IPF patients who were non-infected (Group 1), infected with bacteria only (Group 2), infected with virus only (Group 3) and coinfected with virus and bacteria (Group 4). In this study, there was a significant decrease in FVC values (\% predicted) in IPF patients who were coinfected with virus and bacteria compared with patients were non-infected ( $p=0.013$; Table 2$)$. There was also a significant difference in DLCO values (\% predicted) in IPF patients who were infected with bacteria $(p=0.030$; Table 2) or coinfected ( $p=0.001$; Table 2$)$, respectively, compared with non-infected IPF patients. There was no significant difference in FEV1 values (\% predicted) in noninfected (Group 1) compared with any of the infected groups of IPF patients (Groups 2, 3 and 4).

\section{Effect of bacterial-, viral- and co-infection in on disease status, survival status and survival time on IPF patients at 60-month follow-up}

Three important factors including disease status (AEIPF versus stable-IPF), survival status (death vs. survive)
Table 1 Baseline characteristics of the IPF patients $(n=67)$

\begin{tabular}{|c|c|}
\hline \multicolumn{2}{|l|}{ Characteristics } \\
\hline Age (year) ${ }^{*}$ & $62.8 \pm 12.44$ \\
\hline $\mathrm{FVC}^{*}$ & $75.3 \pm 4.37$ \\
\hline $\mathrm{FEV}_{1}^{*}$ & $70.9 \pm 4.30$ \\
\hline $\mathrm{DL}_{\mathrm{CO}}^{*}$ & $70.5 \pm 3.96$ \\
\hline \multicolumn{2}{|l|}{$\operatorname{Sex}^{+}$} \\
\hline Male & $40(59.7)$ \\
\hline Female & $27(40.3)$ \\
\hline \multicolumn{2}{|l|}{ Disease status ${ }^{+}$} \\
\hline Acute exacerbation & $55(82.1)$ \\
\hline (AE-IPF) stable & $12(17.9)$ \\
\hline \multicolumn{2}{|c|}{ Immunosuppression drugs ${ }^{+}$} \\
\hline Pred 5 mg & $2(3)$ \\
\hline Pred 10 mg & $5(7.5)$ \\
\hline Pred 20 mg & $2(3)$ \\
\hline CyA 125 mg & $2(3)$ \\
\hline Unknown & $8(11.9)$ \\
\hline \multicolumn{2}{|l|}{ Surgical lung biopsy ${ }^{+}$} \\
\hline No & $63(94)$ \\
\hline Yes & $4(6)$ \\
\hline \multicolumn{2}{|c|}{ History of fibrosis in family ${ }^{+}$} \\
\hline No & $55(82.1)$ \\
\hline Yes & $12(17.9)$ \\
\hline \multicolumn{2}{|c|}{ Bacterial infection No. 7 (10.4\%) } \\
\hline P. aeruginosa ${ }^{+}$ & $17(27)$ \\
\hline S.pneumonia ${ }^{+}$ & $17(27)$ \\
\hline S. aureus ${ }^{+}$ & $16(25.4)$ \\
\hline K.pneumoniae ${ }^{+}$ & $16(25.4)$ \\
\hline H. influenzae ${ }^{+}$ & $29(46)$ \\
\hline \multicolumn{2}{|c|}{ Viral infection No. 12 (17.9\%) } \\
\hline Parainfluenza ${ }^{+}$ & $12(19)$ \\
\hline Influenza+ & $12(19)$ \\
\hline Adeno $^{+}$ & $10(15.9)$ \\
\hline Rhinovirus $^{+}$ & $25(39.7)$ \\
\hline $\mathrm{RSV}^{+}$ & $15(23.8)$ \\
\hline Coronavirus $^{+}$ & $9(14.3)$ \\
\hline \multicolumn{2}{|c|}{ Co-infection $^{+}$No. 40 (59.7\%) } \\
\hline \multicolumn{2}{|c|}{ Death $^{+}$} \\
\hline No & $49(73.1)$ \\
\hline Yes & $18(26.9)$ \\
\hline
\end{tabular}

Ref. considered as the reference level for each categorical variable, NA not available, forced vital capacity, FVC forced expiratory volume $1, F E V_{1}$, diffusing capacity of lung for carbon monoxide: $\mathrm{DL}_{\mathrm{CO}}$

* Indicated as mean \pm standard deviation

+ Indicated as " $\mathrm{n}$ " (\%)

and survival time (months-to-death) were investigated in non-infected, viral infected, bacterial infected and coinfected IPF patients (Table 3). In this study, we demonstrated that IPF patients who were coinfected had more unstable disease, had a higher incidence of death 
Table 2 Comparison of pulmonary function indices between non-infected, bacterial-, viral- and co-infected IPF patients, respectively

\begin{tabular}{|c|c|c|c|c|c|c|c|}
\hline PFT index & $\begin{array}{l}\text { Non-infected } \\
\text { Group } 1(\mathrm{n}=8)\end{array}$ & $\begin{array}{l}\text { Bacterial Infection } \\
\text { Group } 2(\mathrm{n}=7)\end{array}$ & $\begin{array}{l}\text { Viral Infection } \\
\text { Group } 3(n=12)\end{array}$ & $\begin{array}{l}\text { Coinfection } \\
\text { Group } 4(n=40)\end{array}$ & $\mathrm{R}, \mathrm{Adj} . p^{*}$ & R, Adj. $p^{+}$ & $\mathrm{R}, \mathrm{Adj} . p^{\$}$ \\
\hline FVC & $79.7 \pm 3.30$ & $76.6 \pm 5.19$ & $77.8 \pm 2.88$ & $73.7 \pm 4.08$ & $0.961,0.368$ & $0.976,0.652$ & $0.924, \mathbf{0 . 0 1 3}$ \\
\hline $\mathrm{FEV}_{1}$ & $73.5 \pm 5.0$ & $73.1 \pm 5.55$ & $73.1 \pm 3.39$ & $69.5 \pm 3.82$ & $0.994,0.996$ & $0.994,0.992$ & $0.945,0.152$ \\
\hline $\mathrm{DL}_{\mathrm{CO}}$ & $76.5 \pm 1.29$ & $71.7 \pm 4.64$ & $71.2 \pm 2.73$ & $69.3 \pm 3.70$ & $0.937,0.076$ & $0.93, \mathbf{0 . 0 3 0}$ & $0.905, \mathbf{0 . 0 0 1}$ \\
\hline
\end{tabular}

Data represents Mean \pm SD

IPF uninfected patients are considered as the reference group (Group 1). The Adj. P is based on the marginally adjusted $p$ values by the Benjamini-Hochberg-FDR correction at $\mathrm{a}=0.05$. Bold values indicated as statistically significant at $p<0.05$ level

PFT pulmonary function test, $R$ ratio

* Comparison between group 2 versus group 1

+ Comparison between group 3 versus group 1

${ }^{\$}$ Comparison between group 4 versus group 1

Table 3 Comparison of disease status, survival time and death occurrence between non-infected, bacterial-, viral- and co-infected IPF patients, respectively

\begin{tabular}{|c|c|c|c|c|c|c|c|}
\hline Characteristics & $\begin{array}{l}\text { Non-infected } \\
\text { Group } 1(\mathrm{n}=8)\end{array}$ & $\begin{array}{l}\text { Bacterial Infection } \\
\text { Group } 2(\mathrm{n}=7)\end{array}$ & $\begin{array}{l}\text { Viral Infection } \\
\text { Group } 3(\mathrm{n}=12)\end{array}$ & $\begin{array}{l}\text { Coinfection } \\
\text { Group } 4(n=40)\end{array}$ & $p^{*}$ & $p^{+}$ & $p^{\$}$ \\
\hline Disease status ${ }^{-}$(acute vs. stable) & 0 & $1(14.3)$ & $1(8.3)$ & $22(55)$ & 0.675 & 0.930 & $<0.001$ \\
\hline Death status ${ }^{-}$(death vs. survive) & 0 & $2(28.5)$ & 0 & $15(37.5)$ & 0.40 & 0.622 & 0.043 \\
\hline Survival time ${ }^{+}$(months-to-death) & $42.5 \pm 6.55$ & $38.5 \pm 7.02$ & $34.4 \pm 2.83$ & $32.9 \pm 9.12$ & 0.426 & 0.193 & 0.026 \\
\hline
\end{tabular}

Disease- and death-status are indicated as " $n$ " (\%). Survival time is indicated as median $\pm I Q R$

IPF uninfected patients are considered as the reference group (Group 1). Bold values indicated as statistically significant at $p<0.05$ level. Follow up period is 60 months

* Comparison between group 2 versus group 1

+ Comparison between group 3 versus group 1

\$Comparison between group 4 versus group 1

and a short survival time compared with non-infected IPF patients. Specifically, a significantly greater percentage of coinfected IPF patients (55\%) were found to be in the $\mathrm{AE}$ phase of disease compared with non-infected patients $(0 \%)(p<0.001$; Table 3$)$. This suggests that virus and bacterial coinfection led to an increase in the severity of the disease. Investigation of the number of deaths within the IPF study cohort revealed that a significantly greater percentage of coinfected IPF patients $(37.5 \%)$ died compared with non-infected patients $(0 \%)$ $(p=0.043$; Table 3). An investigation of the survival time from diagnosis (months-to-death) in IPF patients demonstrated that survival time in coinfected patients $(32.9 \pm 9.12$ months) was significantly less than survival in non-infected IPF patients (42.5 \pm 6.55 months) $(p=0.026$; Table 3). Furthermore, Fig. 1, using KaplanMeier survival curve analysis and the log-rank test, we demonstrated that IPF patients who were co-infected (blue line) had a significantly increased risk of mortality compared (Log rank text: $p=0.031$ ) with IPF patients who were non-infected (black line) [Hazard ratio: 8.12; 95\% confidence interval (CI) 1.3-26.9].

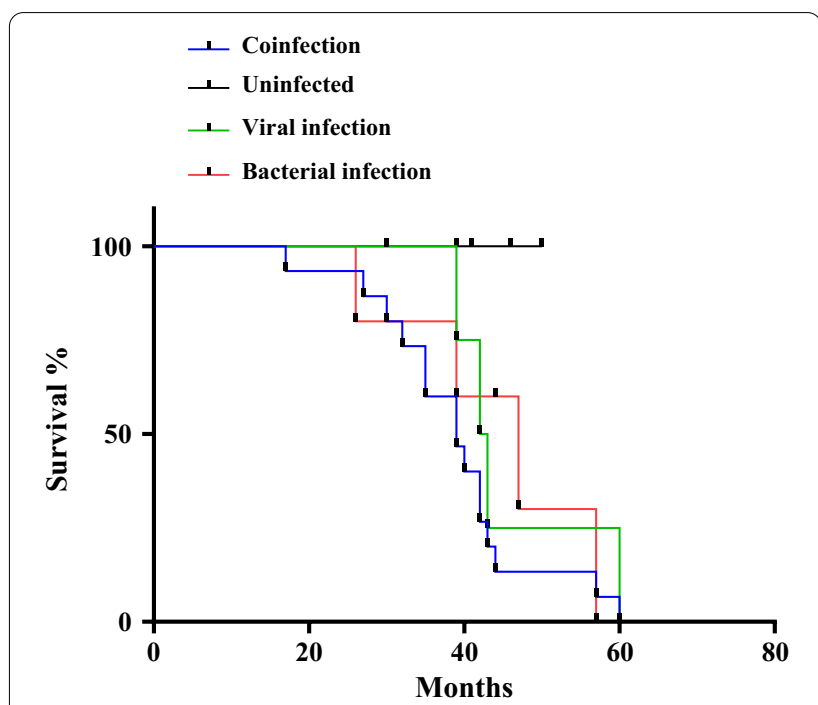

Fig. 1 Kaplan-Meier survival curve analysis for comparison of time until death (in months) between uninfected (black line) and bacterial—-(red line), viral — (green line) and co-infected (blue line) IPF patients. Coinfected IPF patients had a significantly increased risk of death compared with uninfected patients [Log rank test: $p=0.031$; Hazard ratio: $8.12 ; 95 \% \mathrm{Cl} 1.3-26.9$ ] 
Principal component analysis (PCA) of uninfected, viral-, bacterial- and co-infected IPF patients

Based on Kaplan-Meier curves and log-rank test, we established that IPF patients who are coinfected with virus and bacteria have significantly reduced FVC and DLCO (\% predicted), an increased rate of AE-IPF, an increased incidence of death and risk of mortality, and

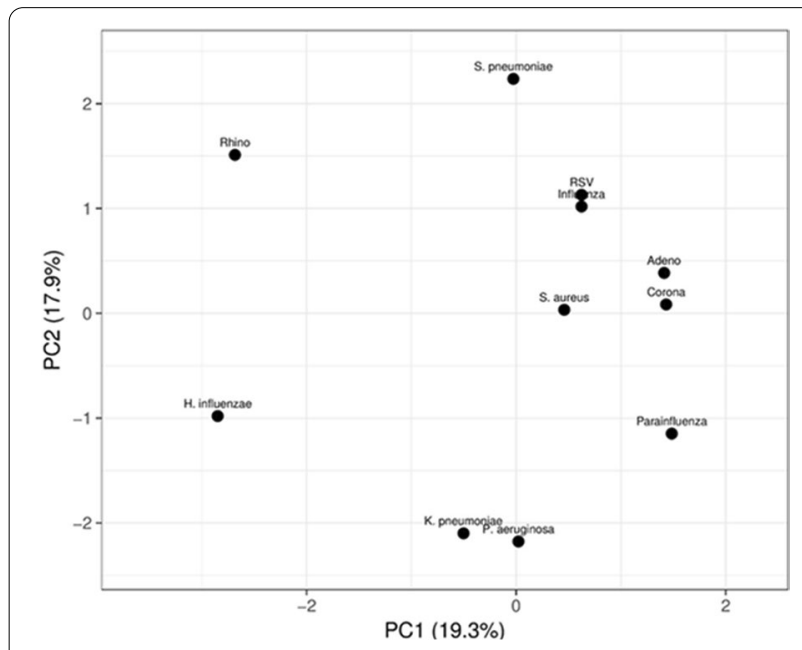

Fig. 2 Principal component analysis (PCA) score plot depicting the relationship between bacterial-, viral- and co-infection groups according to PCA based on the first and second principal components for $n=67$ IPF patients a reduced survival time from months-to-death from diagnosis, respectively, compared with non-infected IPF patients. Here, we employed principal component analysis (PCA), based on the first and second components of the IPF patients included in this study in order to investigate the pattern of bacterial and virus infections, and coinfection in these patients. (Fig. 2). In the PCA score plot, the viral infections (1) RSV and influenza and (2) adenovirus and coronavirus have the most similar coinfection patterns. In the context of bacterial infection, $K$. pneumonia and $P$. aeruginosa have the most similar co-infection pattern.

\section{Analysis of longitudinal decline in FVC in uninfected, viral-, bacterial- and co-infected IPF patients over a 60-month follow-up period}

Analysis of FVC change (\% predicted) from baseline was carried out over a 60-month period post-diagnosis as a predictor of IPF disease progression and mortality risk (Fig. 3). We observed a significant decline in FVC change in IPF patients with bacterial infection $(p<0.001)$, viral infection $(p<0.001)$ and co-infection $(p<0.0001)$ compared with uninfected patients. Furthermore, the decline in FVC was significantly greater in co-infected IPF patients compared with patients infected with bacteria $(p<0.001)$ or virus only $(p<0.001)$.

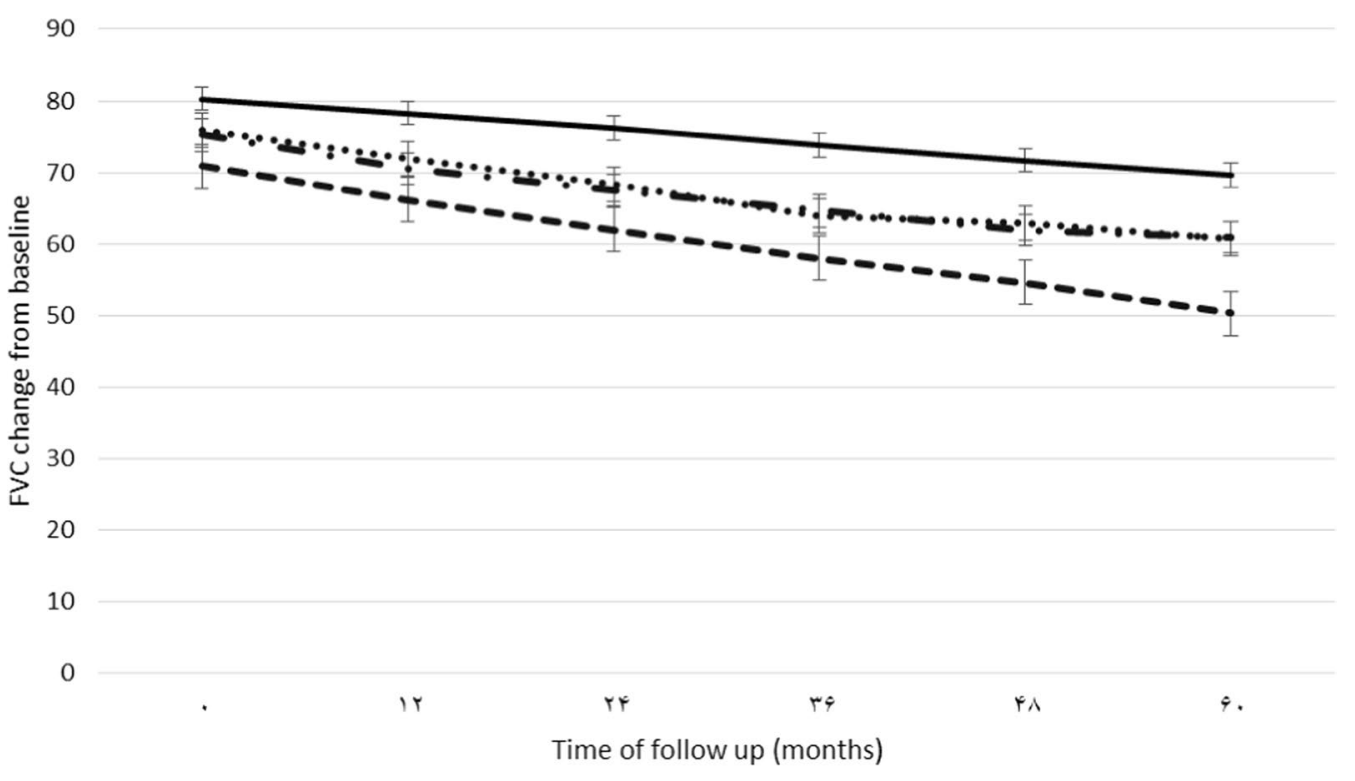

Fig. 3 Time-trend analysis of FVC changes from baseline to 60 months after IPF diagnosis. $p$ value (uninfected vs. coinfection) $<0.0001$. $p$ value (uninfected vs. viral infection) $<0.001$. $p$ value (uninfected vs. bacterial infection) $<0.001$. $p$ value (viral infection vs. bacterial infection) $=0.679$. $p$ value (coinfection vs. viral infection) $<0.001$. $p$ value (coinfection vs. bacterial infection) $<0.001$ 


\section{Discussion}

Recent studies have led to the implication of viral or bacterial infections in both the initiation and progression of IPF [5, 11, 13, 16-19]. Previously, viral infection was hypothesized to play a predominant role in the initiation and the progression of IPF [20]. However, more recently a role for bacterial infection has also been implicated in the development of rapidly progressive IPF $[11,13,18]$. Optimal antiviral and antibacterial immunity are vital in the maintenance of lung homeostasis and health in IPF patients.

In this study, we investigated for the first time, the effect of bacterial, viral and co-infection in disease progression in IPF. Here, we demonstrate that IPF patients who are co-infected with bacterial and viral infection has significantly worsened FVC and $\mathrm{DL}_{\mathrm{CO}}$ function, a greater AE-IPF and reduced survival compared with uninfected patients. Longitudinal rate of decline in FVC (\% predicted) is a well-established marker of disease progression and known predictor of mortality in IPF [21, 22]. In this study, these effects were associated with a significantly greater risk of mortality (Hazards Ratio: 8.12; 95\% CI 1.3-26.9; $p=0.031)$ using Kaplan Meier survival curve analysis over a period of 60 months follow-up. These results suggest that the status of co-infection in IPF patients may be a good prognostic factor for accelerated disease progression. Additionally, these results suggest that the use of antiviral and/or antibacterial therapies may be useful in treating disease progression in co-infected IPF patients. Currently, clinical trials are underway to investigate the efficacy of the macrolidetype antibiotic, Azithromycin (AZT; ClinicalTrials.gov Identifier: NCT02173145). The antiviral, Valganciclovir, is currently being investigated as an adjuvant therapy with Pirfenidone, in the AE-IPF in patients with a history of $\mathrm{CMV}$ infection (ClinicalTrials.gov Identifier: NCT02871401).

AE-IPF are episodes of acute respiratory worsening of unknown cause which may become fatal [13]. Evidence has also suggested that viral infection is responsible for a percentage of acute exacerbations in IPF, which can lead to a rapid deterioration in health [19]. Many patients describe a viral type prodrome before the initial development of respiratory stress in IPF [23]. Currently, there is a growing body of evidence to suggest that bacterial infection, in addition to viral infection, plays a role in AE-IPF [13]. In 2017, Molyneaux et al. demonstrated that there is increased bacterial burden in BAL fluids of IPF patients experiencing AE-IPF compared with stable patients [13]. In this study, we demonstrated that $82.1 \%$ IPF patients who were co-infected with bacteria and virus experienced AE-IPF compared with $10.4 \%$ patients with bacterial infection only and $17.9 \%$ of virus infected patients only. These results suggest a cumulative effect of bacterial and viral infection in the AE-IPF. In order to confirm this, a larger study cohort would be needed.

Using PCA analysis in this study, we demonstrated the following co-infection patterns in IPF patients NPL and BAL fluid samples: (1) coronavirus, parainfluenza virus and adenovirus, (2) rhinovirus and S. pneumonia, (3) $H$. influenza, K. pneumonia and P. aeruginosa, (4) RSV, Influenza and $S$. aureus have similar co-infection patterns. The co-infection pattern of virus and bacteria is of particular interest. Previous studies have shown that viral infection can predispose to bacterial superinfection. Bacterial superinfection of the lung during influenza infection promotes severe disease pathogenesis and leads to increased mortality [24]. Influenza infection can also predispose individuals to $S$. aureus superinfection [25], which is a co-infection pattern observed in our IPF samples. The ability of influenza to facilitate bacterial superinfection in IPF patients underlines a mechanism by which bacterial and viral co-infected IPF patients may experience increased disease progression, mortality risk and reduced lung function as observed in this study.

We previously established that toll-like receptor 3 in an important protective factor against rapid disease progression in IPF [26, 27]. TLR3 is a member of the toll-like receptor superfamily of pathogen recognition receptors (PRRs) [28]. It has previously been shown to bind dsRNA from viruses, bacteria and helminths, respectively, in addition to mRNA released from necrotic cells [29-32]. Recently, our laboratory demonstrated that the TLR3 SNP, Leu412Phe (TLR3 L412F, rs3775291), which results in defective TLR3 function, is associated with a significantly greater risk of mortality and an accelerated rate of decline in FVC of lung function in IPF patients [26, 33]. Our recent data demonstrates that 412F-heterozygous IPF patients have reduced responses to viral dsRNA and a number of bacterial agonists [26]. We suggest that bacterial and viral co-infection will have a much more deleterious effect in IPF patients who have defective TLR3 function, and are 412F-heterozygous.

In this study, we used NPL and BAL fluid in our to quantitate bacterial and viral infection in IPF patients. However, IPF is a lung disease which affects the parenchymal tissue. In order to assess the level of co-infection in lung tissue, it would be necessary to perform a videoassisted thoracic surgery (VATS) biopsy on patients. These biopsies are associated with considerable risk for the patient and have appreciable rates of morbidity and mortality. Therefore, analysis of co-infection in parenchymal IPF lung is not a viable option. However, it is promising to note that quantitation of levels co-infection in distal IPF samples, such as NPL and BAL fluid, can give significant results which are linked to accelerated disease 
progression, increased AE-IPF and increased mortality risk. Our study is not without limitations. The main limitations of this study are its retrospective nature and small sample size. The retrospective nature of this study limiting our ability to control for potential confounding factors. Also, low sample size in studied groups could be effect on power of the statistical tests.

\section{Conclusion}

In summary, our results demonstrated that the coinfection is significantly associated with an enhanced risk of death by AE in IPF. Furthermore, this study reveals bacterial and viral co-infection as novel prognostic marker in the treatment of IPF. Further analysis is necessary in order to confirm these findings in a larger cohort of IPF patients.

\section{Abbreviations}

IPF: Idiopathic pulmonary fibrosis; PCA: Principal component analysis; AE-IPF: Acute exacerbations in IPF; NPL: Nasopharyngeal lavage; BAL: Bronchoalveolar lavage; FVC: Forced vital capacity; FEV1: Forced expiratory volume 1; DLCO: Diffusion lung capacity for carbon monoxide; RSV: Respiratory syncytial virus.

\section{Acknowledgements}

The authors deeply acknowledge all the patients who contributed to this study. Also, authors are greatly thankful to the director and staff of all Hospitals for their valuable helps.

\section{Authors' contributions}

MM, SM and FB performed experiments and analysis. NK and MEA analysed data and wrote the paper. FB and MM contributed to manuscript drafting. All authors have read and approved the final manuscript.

\section{Funding}

This work was supported by KUMS by grant number 97694 . The funding body had no role in the design of the study and collection, analysis, and interpretation of data and in writing the manuscript.

\section{Availability of data and materials}

The datasets used and/or analyzed during the current study could become available through the corresponding author on reasonable request.

\section{Declarations}

Ethics approval and consent to participate

Ethical approval for this study was obtained from Kermanshah University of Medical Sciences (IR.KUMS.REC.1397.764). We confirm that written informed consent to participate was obtained from all of the participants in our study. We acquired permissions and/or licenses to access the clinical/personal patient data used in our research from Kermanshah University of Medical Sciences.

\section{Consent for publication}

Not applicable.

\section{Competing interests}

The authors declare that they have no competing interests.

\section{Author details}

${ }^{1}$ Infectious Diseases Research Center, Kermanshah University of Medical Sciences, Kermanshah, Iran. ${ }^{2}$ Department of Microbiology, Faculty of Medicine, Kermanshah University of Medical Sciences, Kermanshah, Iran. ${ }^{3}$ Division of Clinical Geriatrics, Department of Neurobiology, Care Sciences and Society,
Karolinska Institute, Stockholm, Sweden. ${ }^{4}$ Department of Pediatrics, Faculty of Medicine, Kermanshah University of Medical Sciences, Kermanshah, Iran. ${ }^{5}$ Department of Clinical Medicine, School of Medicine, Trinity Biomedical Sciences Institute, Trinity College Dublin, Dublin 2, Ireland.

Received: 10 July 2021 Accepted: 3 February 2022

Published online: 11 February 2022

\section{References}

1. Donnelly SC. Review series-inflammation and fibrosis. Introduction. QJM. 2012;105:503.

2. Raghu G, Collard HR, Egan JJ, Martinez FJ, Behr J, Brown KK, Colby TV, Cordier J-F, Flaherty KR, Lasky JA. An official ATS/ERS/JRS/ALAT statement: idiopathic pulmonary fibrosis: evidence-based guidelines for diagnosis and management. Am J Respir Crit Care Med. 2011;183:788-824.

3. Borchers AT, Chang C, Keen CL, Gershwin ME. Idiopathic pulmonary fibrosis_-an epidemiological and pathological review. Clin Rev Allergy Immunol. 2011;40:117-34.

4. Keyvani H, Moghoofei M, Bokharaei-Salim F, Mostafaei S, Mousavi S-AJ, Monavari SH, Esghaei M. Prevalence of respiratory viruses in Iranian patients with idiopathic pulmonary fibrosis. J Med Microbiol. 2017:66:1602-6.

5. Moore BB, Moore TA. Viruses in idiopathic pulmonary fibrosis. Etiology and exacerbation. Ann Am Thorac Soc. 2015;12(Suppl 2):S186-192.

6. Yonemaru M, Kasuga I, Kusumoto H, Kunisawa A, Kiyokawa H, Kuwabara S, Ichinose Y, Toyama K. Elevation of antibodies to cytomegalovirus and other herpes viruses in pulmonary fibrosis. Eur Respir J. 1997;10:2040-5.

7. Lasithiotaki I, Antoniou KM, Vlahava VM, Karagiannis K, Spandidos DA, Siafakas NM, Sourvinos G. Detection of herpes simplex virus type-1 in patients with fibrotic lung diseases. PLoS ONE. 2011;6:e27800.

8. Ueda T, Ohta K, Suzuki N, Yamaguchi M, Hirai K, Horiuchi T, Watanabe J, Miyamoto T, Ito K. Idiopathic pulmonary fibrosis and high prevalence of serum antibodies to hepatitis C virus. Am Rev Respir Dis. 1992;146:266-8.

9. Umeda Y, Morikawa M, Anzai M, Sumida Y, Kadowaki M, Ameshima S, Ishizaki T. Acute exacerbation of idiopathic pulmonary fibrosis after pandemic influenza A (H1N1) vaccination. Intern Med. 2010;49:2333-6.

10. Collard HR, Moore BB, Flaherty KR, Brown KK, Kaner RJ, King TE Jr, Lasky JA, Loyd JE, Noth I, Olman MA. Acute exacerbations of idiopathic pulmonary fibrosis. Am J Respir Crit Care Med. 2007;176:636-43.

11. Molyneaux PL, Cox MJ, Willis-Owen SA, Mallia P, Russell KE, Russell AM, Murphy E, Johnston SL, Schwartz DA, Wells AU, et al. The role of bacteria in the pathogenesis and progression of idiopathic pulmonary fibrosis. Am J Respir Crit Care Med. 2014;190:906-13.

12. Moghoofei M, Jamalkandi SA, Moein M, Salimian J, Ahmadi A. Bacterial infections in acute exacerbation of chronic obstructive pulmonary disease: a systematic review and meta-analysis. Infection. 2020;48:19-35.

13. Molyneaux PL, Cox MJ, Wells AU, Kim HC, Ji W, Cookson WO, Moffatt MF, Kim DS, Maher TM. Changes in the respiratory microbiome during acute exacerbations of idiopathic pulmonary fibrosis. Respir Res. 2017;18:29.

14. Tyler S, Strathdee C, Rozee K, Johnson W. Oligonucleotide primers designed to differentiate pathogenic pseudomonads on the basis of the sequencing of genes coding for 16S-23S rRNA internal transcribed spacers. Clin Diagn Lab Immunol. 1995;2:448-53.

15. Turton JF, Perry C, Elgohari S, Hampton CV. PCR characterization and typing of Klebsiella pneumoniae using capsular type-specific, variable number tandem repeat and virulence gene targets. J Med Microbiol. 2010;59:541-7.

16. Vannella KM, Moore BB. Viruses as co-factors for the initiation or exacerbation of lung fibrosis. Fibrogenesis Tissue Repair. 2008;1:2.

17. Naik PK, Moore BB. Viral infection and aging as cofactors for the development of pulmonary fibrosis. Expert Rev Respir Med. 2010;4:759-71.

18. Molyneaux PL, Maher TM. Respiratory microbiome in IPF: Cause, effect, or biomarker? Lancet Respir Med. 2014;2:511-3.

19. Molyneaux PL, Maher TM. The role of infection in the pathogenesis of idiopathic pulmonary fibrosis. Eur Respir Rev. 2013;22:376-81.

20. Meneghin A, Hogaboam CM. Infectious disease, the innate immune response, and fibrosis. J Clin Investig. 2007;117:530-8. 
21. Collard HR, King TE Jr, Bartelson BB, Vourlekis JS, Schwarz MI, Brown KK. Changes in clinical and physiologic variables predict survival in idiopathic pulmonary fibrosis. Am J Respir Crit Care Med. 2003;168:538-42.

22. Latsi PI, du Bois RM, Nicholson AG, Colby TV, Bisirtzoglou D, Nikolakopoulou A, Veeraraghavan S, Hansell DM, Wells AU. Fibrotic idiopathic interstitial pneumonia: the prognostic value of longitudinal functional trends. Am J Respir Crit Care Med. 2003;168:531-7.

23. Golden A, Bronk TT. Diffuse interstitial fibrosis of lungs; a form of diffuse interstitial angiosis and reticulosis of the lungs. AMA Arch Intern Med. 1953;92:106-14

24. Hendaus MA, Jomha FA, Alhammadi AH. Virus-induced secondary bacterial infection: a concise review. Ther Clin Risk Manag. 2015;11:1265-71.

25. Robinson KM, Ramanan K, Clay ME, McHugh KJ, Pilewski MJ, Nickolich KL, Corey C, Shiva S, Wang J, Muzumdar R, Alcorn JF. The inflammasome potentiates influenza/Staphylococcus aureus superinfection in mice. JCl Insight. 2018;3:e97470.

26. O'Dwyer DN, Armstrong ME, Trujillo G, Cooke G, Keane MP, Fallon PG, Simpson AJ, Millar AB, McGrath EE, Whyte MK, et al. The toll-like receptor $3 \mathrm{~L} 412 \mathrm{~F}$ polymorphism and disease progression in idiopathic pulmonary fibrosis. Am J Respir Crit Care Med. 2013;188:1442-50

27. O'Dwyer DN, Armstrong ME, Kooblall M, Donnelly SC. Targeting defective Toll-like receptor-3 function and idiopathic pulmonary fibrosis. Expert Opin Ther Targets. 2015;19:507-14.

28. O'Neill LA, Golenbock D, Bowie AG. The history of Toll-like receptorsredefining innate immunity. Nat Rev Immunol. 2013;13:453-60.

29. Alexopoulou L, Holt AC, Medzhitov R, Flavell RA. Recognition of doublestranded RNA and activation of NF-kappaB by Toll-like receptor 3. Nature. 2001:413:732-8.

30. Spelmink L, Sender V, Hentrich K, Kuri T, Plant L, Henriques-Normark B. Toll-like receptor 3/TRIF-dependent IL-12p70 secretion mediated by Streptococcus pneumoniae RNA and Its priming by influenza A virus coinfection in human dendritic cells. MBio. 2016;7:e00168-e116.

31. Aksoy E, Zouain CS, Vanhoutte F, Fontaine J, Pavelka N, Thieblemont N, Willems F, Ricciardi-Castagnoli P, Goldman M, Capron M, et al. Doublestranded RNAs from the helminth parasite Schistosoma activate TLR3 in dendritic cells. J Biol Chem. 2005;280:277-83.

32. Cavassani KA, Ishii M, Wen H, Schaller MA, Lincoln PM, Lukacs NW, Hogaboam CM, Kunkel SL. TLR3 is an endogenous sensor of tissue necrosis during acute inflammatory events. J Exp Med. 2008;205:2609-21.

33. Noth I, Kaminski N. Idiopathic pulmonary fibrosis: Time to get personal? Am J Respir Crit Care Med. 2013;188:1392-4.

\section{Publisher's Note}

Springer Nature remains neutral with regard to jurisdictional claims in published maps and institutional affiliations.

Ready to submit your research? Choose BMC and benefit from:

- fast, convenient online submission

- thorough peer review by experienced researchers in your field

- rapid publication on acceptance

- support for research data, including large and complex data types

- gold Open Access which fosters wider collaboration and increased citations

- maximum visibility for your research: over 100M website views per year

At BMC, research is always in progress.

Learn more biomedcentral.com/submissions 